Int. J. Dev. Biol. 56: 313-323 (2012)

doi: $10.1387 / \mathrm{ijdb} .123522 \mathrm{mh}$

\title{
Induction of differentiation of undifferentiated cells into pancreatic $\beta$-cells in vertebrates
}

\author{
MASAKI HOSOYA ${ }^{*}, 1$, YUYA KUNISADA ${ }^{1}$, AKIRA KURISAKI ${ }^{2}$ and MAKOTO ASASHIMA*,2 \\ ${ }^{1}$ Advanced Science Research Laboratories, Pharmaceutical Research Division, Takeda Pharmaceutical Company \\ Limited, Fujisawa, Kanagawa and ${ }^{2}$ Research Center for Stem Cell Engineering, National Institute of Advanced \\ Industrial Science and Technology, Tsukuba, Ibaraki, Japan
}

\begin{abstract}
The $\beta$-cells of the pancreatic islets, which maintain glucose homeostasis by secreting insulin, are important cells for sustaining life. In recent years, islet transplantation has been performed as a treatment for type I diabetes. Since there are not enough donors for patients awaiting transplantation, $\beta$-cells grown in vitro are expected to be utilized as a substitute for islets. To obtain the cells with properties of human $\beta$-cells, it is necessary to understand the process by which human pancreatic islets are formed, as well as their structural characteristics. By using undifferentiated cells, such as Xenopus laevis animal caps and mouse ES cells, pancreatic tissue has shown to be able to be induced in vitro. Various attempts have been made to obtain human $\beta$-cells from human ES/iPS cells. Versatile methods have been developed and improved efficiency has been achieved by the use of low molecular weight compounds, but the challenge remains to prevent tumor formation and achieve functional maturation. Inducing the differentiation of somatic stem cells into insulin-producing cells has also brought us closer to clinical application. There are still many challenges related to the practical use of $\beta$-cells derived from undifferentiated cells, such as the development of methods to substitute these cells for host $\beta$-cells, standardization of the treatment protocol, quality control, and confirmation of safety. Research on the methods of inducing undifferentiated cells to differentiate into $\beta$-cells has shown definite progress, suggesting that cell therapy for diabetes may become a preferred therapeutic option over islet transplantation.
\end{abstract}

KEY WORDS: undifferentiated cell, pancreatic $\beta$-cell, insulin, diabetes, transplantation

\section{Introduction}

During embryonic development, the pancreas is derived from the endoderm. The pancreas is an exocrine gland that secretes pancreatic juice containing digestive enzymes into the gastrointestinal tract, but it has additional endocrine functions in all vertebrates from amphibians onward (Heller, 2010). The endocrine cells of the pancreas form masses called islets of Langerhans (pancreatic islets) (In't Veld and Marichal, 2010). All of the hormones secreted by the pancreatic islets are involved in regulating metabolism, and the blood glucose concentration is maintained within a relatively narrow range as a result of their actions. While glucose is the principal carbohydrate in the blood and is an important nutrient that carries energy to every part of the body, excessively high blood glucose levels cause fatal damage to variety of organs (Stolar, 2010). Insulin is a hormone produced by pancreatic $\beta$-cells that has the unique action of lowering blood glucose, and thus is an especially important hormone for sustaining life.

Pancreatic $\beta$-cells synthesize and secrete insulin in response to an increase of the blood glucose level in order to maintain it within the normal range. When a state arises in which the control of blood glucose becomes impossible due to an absolute deficiency of insulin resulting from loss or dysfunction of pancreatic $\beta$-cells, or because of increased peripheral resistance to the actions of insulin, diabetes mellitus is diagnosed. If hyperglycemia persists for a long period, complications such as neuropathy, retinopathy, and nephropathy can occur, along with organ dysfunction or lower limb gangrene (amputation) resulting from vascular disease. Such

Abbreviations used in this paper: EB, embryoid body; EBS, embryoid body-like sphere; EpiSC, epistem cell.

\footnotetext{
*Address correspondence to: Masaki Hosoya. Advanced Science Research Laboratories, Pharmaceutical Research Division,Takeda Pharmaceutical Company Limited 26-1, Muraoka-higashi 2-chome, Fujisawa, Kanagawa, 251-8555, Japan. e-mail: masaki.hosoya@ takeda.com or Makoto Asashima. Research Center for Stem Cell Engineering, National Institute of Advanced Industrial Science and Technology, 1-1-1 Higashi,Tsukuba, Ibaraki 305-8561, Japan. e-mail: m-asashima@aist.go.jp
} 
complications are a major obstacle to the diabetic patient enjoying daily activities and health, as well as threatening survival, so treatment of diabetes is extremely important (Dailey, 2011). Insulin was first obtained in 1921, and it has since been used by a very large number of diabetic patients. In recent years, drugs that stimulate insulin secretion or improve insulin resistance have been developed, and it has become possible to better regulate the blood glucose level of diabetic patients (Tahrani et al., 2011). However, daily blood glucose monitoring and insulin injections are still required if a patient's insulin production is exhausted, as occurs with type 1 diabetes or advanced type 2 diabetes, and alleviating this burden has become an objective of antidiabetic therapy. Moreover, insulin has other functions besides regulating blood glucose levels, so maintenance of basal insulin secretion is also very important (Niswender, 2011).

Because pancreatic $\beta$-cells do not simply produce and secrete insulin at a constant rate, but supply the amount needed in a timely manner, insulin dependence is expected to be alleviated by transplanting the pancreas, by regenerating pancreatic $\beta$-cells, or by transplanting pancreatic islets. With the objective of reducing surgical stress on the patient, research into pancreatic islet transplantation has been ongoing for many years (Emamaullee and Shapiro, 2008). After the Edmonton protocol modified the immunosuppressant regimen (Shapiro et al., 2000), pancreatic islet transplantation has been widely adopted in recent years. Although long-term freedom from insulin therapy has not been achieved so far, improvement of glycemic control is seen in many cases. However, due to the failure of some islets to function after transplantation, pancreatic islets from more than one donor are needed to treat each patient in order to ensure efficacy. Therefore, a shortage of donors has become a problem. Since pancreatic islet transplantation is performed for the treatment of chronic pancreatitis associated with extreme pain, as well as for diabetes, technical improvements to this therapy are ongoing (Matsumoto, 2011).

Pancreatic $\beta$-cell regeneration is one of the technologies that has attracted attention for overcoming the shortage of pancreatic islet donors (Guo and Hebrock, 2009; Weir et al., 2011, Wen et al., 2011). Because of the difficulty in culturing pancreatic $\beta$-cells harvested from donors and maintaining their properties during proliferation, other sources of cells for transplantation have been explored. Recently, development of methods for inducing functional pancreatic $\beta$-cells from easily grown undifferentiated cells, such as human ES cells (Thomson et al., 1998) or the recently discovered human induced pluripotent stem cells (iPS) (Takahashi et al., 2007; Yu et al., 2007; Okita et al., 2011), has been investigated worldwide (Weir et al., 2011; Wen et al., 2011). Since pancreatic $\beta$-cells have the unique property of synthesizing and secreting insulin in response to an increase of the blood glucose concentration, inducing the differentiation of these cells is also interesting from a scientific standpoint.

\section{Structure and development of the pancreas and pan- creatic islets}

Before conducting research on regeneration of the pancreas and pancreatic islets, it is necessary to understand their structure and development. There have already been many reviews published on the differentiation of the pancreas and the pancreatic endocrine system (Murtaugh, 2007; Oliver-Krasinski and Stoffers,
2008; Puri and Hebrok, 2010; Pan and Wright, 2011). However, the important points described below have not been addressed in many of these review articles.

Insulin is a hormone that is widely present in the animal kingdom. In lower animals, cells that secrete insulin are located in the digestive tract instead of the pancreas (Heller, 2010). However, in cyclostomes (Cyclostomata) such as the lamprey, cells that secrete insulin form pancreatic islet-like structures located outside the digestive tract. In higher animals, starting with cartilaginous fish (Chondrichthyes), these cells form pancreatic islets (Heller, 2010). From an evolutionary standpoint, pancreatic endocrine cells are likely to have evolved to produce cell clusters because this morphology is suited to performing their functions efficiently (Madsen, 2007; Heller, 2010). Consistent with these phylogenetic findings, it has been shown that endocrine cell clusters are formed in the mammalian pancreas by migration of cells from the pancreatic epithelium during embryonic development. It has long been known from morphological observation that the islets are formed from the pancreatic epithelium, but the mechanism was only elucidated recently (Greiner et al., 2009). Although migration has an important role in the development of the pancreatic endocrine system, promoting migration in the adult pancreas seemed to be difficult because its structure has been established. We considered that this could be one of the barriers hampering regeneration of the pancreatic endocrine system. The signals that stimulate pancreatic endocrine cells to migrate during embryonic development are not clear, but the G protein-coupled receptor and its ligand sphingosine-1-phosphate have recently been reported to be involved in this process (Serafimidis et al., 2011).

There are interspecies differences in the morphology of the pancreas. For example, there is a marked difference in the appearance of the pancreas between rodents and humans. The rodent pancreas is distributed in a reticular pattern along the mesentery, whereas the pancreas is a discrete wedge-shaped organ in humans. The liver is an organ that actively regenerates and it has a highly developed vascular network. On the other hand the human pancreas has a characteristic vascular system based on the peripancreatic arter-

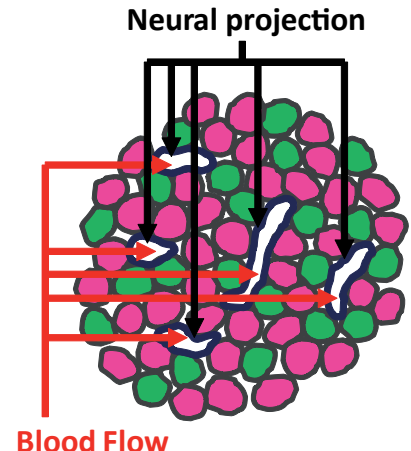

Human islet

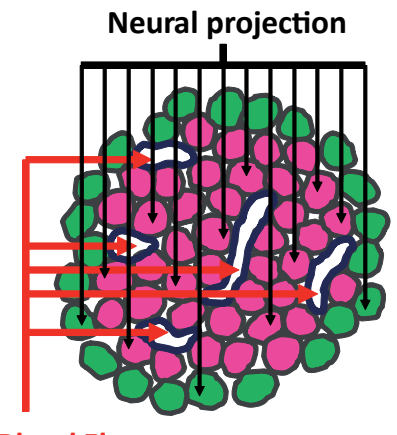

Blood Flow
Mouse islet

Fig. 1. Structural differences between human and mouse pancreatic islets. In the human islet, $\beta$-cells and $\alpha$-cells are intermingled (left). The nerves innervating human islets project to blood vessels but not to endocrine cells. In contrast, the mouse islet (right) has a so-called "mantle core" structure, in which $\beta$-cells form a central cluster and are surrounded by $\alpha$-cells at the periphery. Nerves innervating mouse islets project directly onto the endocrine cells. 
ies (Okahara et al., 2010), and compartmentalization of its blood supply may also be an obstacle to regeneration. The pancreas is usually formed by fusion of two primordia, which are known as the dorsal and ventral pancreatic buds, but in the Asian house shrew (Suncus murinus) the two buds do not merge (Yi et al., 2003). In organ cultures of rat pancreatic primordia, merging of the left and right lobes is not seen either (Spooner et al., 1970). Anatomical comparison between the Asian house shrew and humans has shown that even if the two parts of the pancreas merge, the anatomy of the blood vessels, lymphatics, and nerves in the portions derived from the right and left primordia are different (Yi et al., 2003). In addition, pancreatic polypeptide (PP) cells are found in the right lobe, but are rare in the left lobe (Gersell et al., 1979). In fact, two different types of pancreatic islets are observed during human fetal development, with one type containing few PP cells and the other being almost entirely composed of PP cells (Riedel et al., 2011). This also emphasizes the importance of taking difference between the left and right lobes into account when studying pancreatic differentiation and function.

The structure of the pancreatic islets varies among animal species. Pancreatic endocrine cells have evolved from being predominantly $\beta$-cells to form complex aggregates of 5 different types of endocrine cells (Heller, 2010). The pancreatic islets of rodents have a so-called "mantle-core structure," with $\beta$-cells located at the center and surrounded by $\alpha$-cells, whereas the $\beta$-cells and $\alpha$-cells are intermingled in humans (Fig. 1) (Brissova et al., 2005). Since the pancreatic islets of pigs appear to have aggregates of small mantle-core structures and the pancreatic isles of monkeys are very similar in morphology to those of humans (Brissova et al., 2005), the arrangement of endocrine cells in the islets appears to have changed during the course of evolution. There are other structural components of the pancreatic islets, including blood vessels and nerves (In't Veld and Marichal, 2010). Whereas the pancreatic endocrine cells of rodents are densely innervated by autonomic nerves, human pancreatic endocrine cells receive hardly any direct autonomic innervation (Fig. 1) (Rodriguez-Diaz et al., 2011). In contrast to the endocrine cells, the blood vessels of rodent pancreatic islets only have a sparse nerve supply, whereas the vessels of human pancreatic islets show dense innervation (Fig. 1) (Rodriguez-Diaz et al., 2011). These findings indicate that the role of the autonomic nervous system in regulating pancreatic function differs between humans and rodents.

\section{Differentiation of the pancreas}

Knowledge about pancreatic development has been applied to a variety of approaches toward inducing cultured stem cells to differentiate into pancreatic $\beta$-cells with the aim of developing regenerative medicine for diabetes. Attempts have also been made to promote the proliferation of endogenous pancreatic $\beta$-cells and to induce differentiation of $\beta$-cells from precursor cells or stem cells in situ. Knowledge obtained from investigation of genetically modified animals, in particular, has contributed to elucidating the mechanisms involved in differentiation and re- generation of the pancreas. However, ethical considerations make it impossible to confirm these findings in humans. Since all that can be done is to extrapolate from research performed in animals, attention needs to be paid to potential interspecies differences.

Since it is also ethically impossible to modify human genes to investigate pancreatic development in vivo, anatomical studies have provided the majority of our knowledge about differentiation of the human pancreas. On the other hand, transplantation of pancreatic primordia (excised from human embryos) under the renal capsules of experimental animals allows the process of organogenesis to be observed (Fig. 2). In animal studies, pulse labeling with the nucleic acid analog bromodeoxyuridine (BrdU) by adding it to drinking water allows assessment of cell proliferation in situ. In humans, such studies cannot be performed directly and we can only investigate proliferation after subrenal capsule transplantation of the pancreas into animals. In mice, the $\beta$-cells of adults are reported to have the ability to regenerate (Brennand et al., 2007). On the other hand, studies of the human pancreas have shown that cells expressing NGN3 are not labeled by BrdU (Castaing et al., 2005), suggesting that the size of the pancreatic endocrine system has been determined by that stage. A functional human $\beta$-cell line was recently established by viral immortalization of differentiating cells in the proliferative phase grown under the renal capsule (Ravassard et al., 2011). There are still many restrictions regarding research on human embryos. In order to conduct more detailed research on human pancreatic development, it will be necessary to produce pancreata by culture of multipotent stem cells, such as ES/iPS cells, rather than by harvesting from embryos.

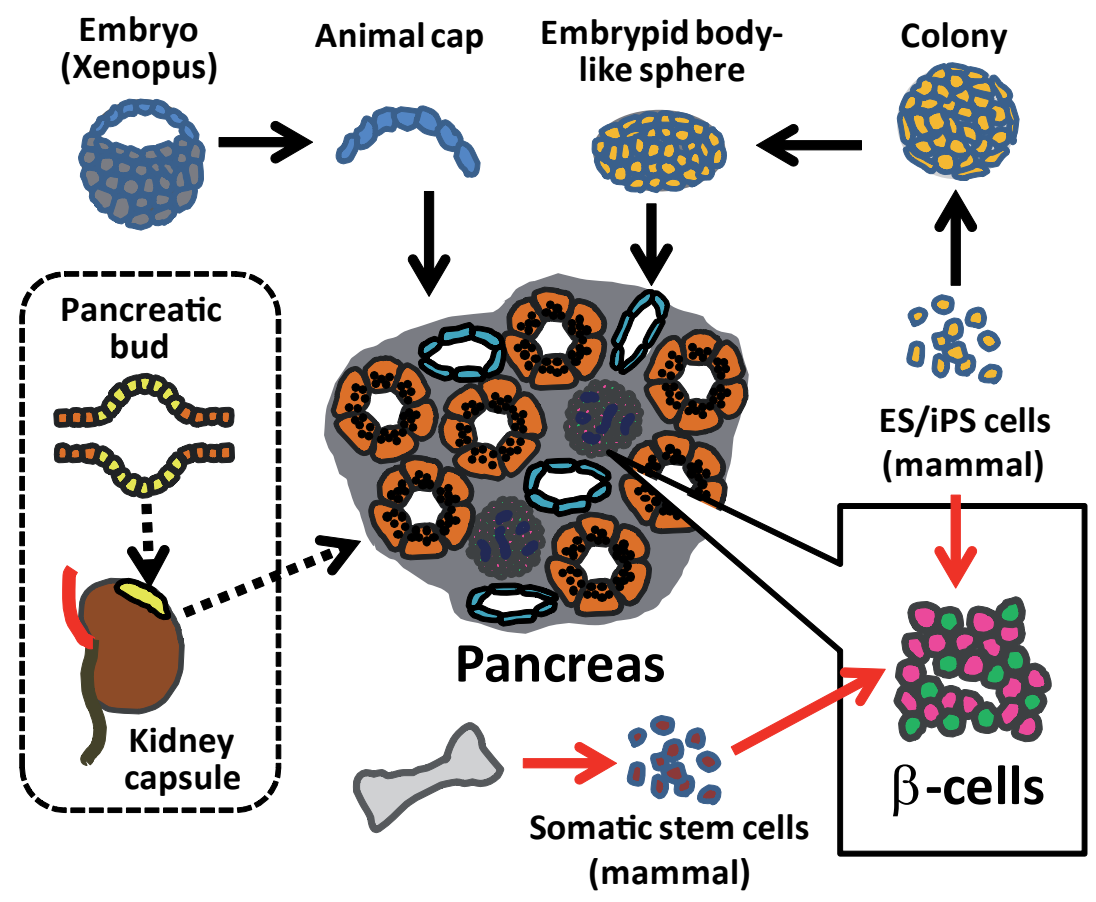

Fig. 2. Strategies for obtaining pancreatic $\beta$-cells from undifferentiated cells. Pancreatic buds autonomously differentiate into pancreatic tissue when isolated and grafted under the kidney capsule in immunodeficient mice (dotted line). In vitro, the animal caps of Xenopus blastulas and embryoid body-like spheres of mouse ES cells can also undergo differentiation into pancreatic tissue (top). Methods for specific induction of $\beta$-cells have been explored by utilizing ES/iPS cells and somatic stem cells (right). 
Selective differentiation of vertebrate multipotent stem cells to form the pancreas in vitro was first demonstrated in a study of the blastular undifferentiated cell mass (animal cap) in Xenopus laevis (Fig. 2) (Moriya et al., 2000a, 2000b). Animal caps can be efficiently differentiated into pancreas-like tissue by incubation with a high concentration of activin, subsequent treatment with retinoic acid, and further culture (Fig. 3). The tissue thus obtained has been confirmed to express insulin and glucagon. Acinar-like cells containing secretory granules have also been identified, confirming that undifferentiated cells can differentiate into pancreatic tissue in vitro. By optimizing the concentrations of activin and retinoic acid, differentiation of a variety of organs can be induced from the animal cap (Asashima et al., 2009). When an animal cap is cultured without stimulation, it becomes amorphous epidermis, but treatment with a low concentration of activin induces blood islands and muscles. When an animal cap is treated with a higher concentration activin, differentiation of the notochord and endodermal cells are also induced. By combining activin with retinoic acid or physical manipulation, it is possible to induce differentiation of 22 different viscera and organs from animal caps. Since reproducible results are obtained with animal caps, sequential sampling and gene expression profiling has allowed us to create gene expression road maps for organogenesis and to discover new markers of pancreatic differentiation (Kurisaki et al., 2010). Combined treatment with activin and retinoic acid was subsequently applied to mouse ES cells, and production of a mammalian pancreas was successfully achieved (Nakanishi et al., 2007). When mouse ES cells were allowed to form embryoid body-like spheres (EBSs) and then were treated with activin and retinoic acid, pancreatic tissue was formed that contained both exocrine and endocrine cells (Fig. 2). Unlike an embryoid body (EB), which is formed by the reaggregation of enzymatically dissociated ES cells, an EBS is derived from a single ES cell. Since EBSs are formed without destroying intercellular adhesions, and their structure is closer to that of the Xenopus animal cap or early mouse embryo, they seem to have some advantages for achieving pancreatic differentiation. It is easy to create EBSs from mouse ES cells, but it is difficult to stimulate human ES cells to form masses of undifferentiated cells. These differing properties of human and mouse ES cells have been explained by their origin at different embryological stages. When mouse epistem cells (EpiSCs) were established from more advanced embryos than the post-implantation embryos used as the source of ES cells, their properties closely resembled those of human ES cells (similar morphology, independence from LIF, and dependence on bFGF to maintain pluripotency, etc.) (Tesar et al., 2007). Mouse ES cells have both chimera-forming and teratomaforming properties, whereas mouse EpiSCs can form teratomas but not chimeras. In the past, it was thought that rat ES cells did not show chimera-forming ability, but chimeras were recently established from these cells by blocking differentiation signals with low molecular weight compounds (Buehr et al., 2008; Li et al., 2008). Based on these findings, two phases of pluripotency known as "naïve" and "primed" have been recognized (Nichols and Smith, 2009). During the blastocyst stage of embryogenesis, unrestricted (naïve) cells are thought to be generated first and then these cells are prepared for lineage commitment (primed). Their properties are duplicated by those of cultured ES cells and EpiSCs. Recently, the optimum culture conditions were reported for rapid phenotypic conversion of human ES cells from primed to naïve cells (Gu et al., 2012). If naïve human ES/iPS cells become routinely available, such cells would be useful for conducting research on in vitro organogenesis through the formation of EBS.

Since a pancreas containing both exocrine cells and endocrine cells can be formed in renal capsule at a site that is completely different from its anatomic location (Castaing et al., 2005), it is assumed that neural involvement is not essential for differentiation of the pancreatic endocrine system. Moreover, since undifferentiated Xenopusanimal caps and mouse ES cells can be selectively induced to differentiate into a functional pancreas in vitro(Moriya et al., 2000a, 2000b, Nakanishi et al., 2007), the circulatory system does not seem to be essential either. On the other hand, the vascular endothelial system is very important for organ development (Crivellato et al., 2007), and differentiation of the endocrine system as well as early differentiation of the pancreas are regulated by signals from blood vessels (Lammert et al., 2001). In contrast, blood vessels are attracted to the pancreatic islets by the secretion of signaling molecules such as IL-1 $\beta$ (Shchors et al., 2006). The mesenchyme also has an important role in pancreatic development (Scharfmann, 2000). To achieve the growth of pancreatic tissue or sufficient endocrine cells for use in treating diabetes, it may be necessary to modify the protocol to stimulate organogenesis, such as by promotion of 
angiogenesis, separately from determining the fate of the pancreatic and endocrine lineages.

In anotherstudy, rat ES/iPS cells were injected into mouse embryos that had lost the ability to form a pancreas by genetic modification, and production of a xenogenic pancreas by "blastocyst complementation" was achieved (Kobayashi et al., 2010). Theoretically, it is also possible for this to be done in large animals, such as pigs. There are ethical problems with producing human-animal chimera embryos. There are also challenges related to their practical use, because it is difficult to completely remove cells derived from the host such as vascular cells. However, if it were possible to produce a human pancreas in this way, it would be an important tool for diabetes research as well as for clinical application.

\section{Selective induction of the differentiation of ES/iPS cells into pancreatic $\beta$-cells}

Mouse ES cells were initially used to develop a method for

\begin{tabular}{|c|c|c|c|c|c|c|c|}
\hline \multirow[b]{2}{*}{ D'Amour et al., 2006} & Step 1 & Step 2 & Step 3 & Step 4 & Step 5 & Step 6 & \\
\hline & $\begin{array}{c}\text { Activin A } \\
\text { Wnt3A }\end{array}$ & $\begin{array}{l}0.2 \% \text { FBS } \\
\text { Activin A }\end{array}$ & $\begin{array}{c}2 \% \text { FBS } \\
\text { FGF10 } \\
\text { Cyclopamine }\end{array}$ & $\begin{array}{c}1 \% \text { B27 } \\
\text { Retinoic Acid } \\
\text { Cyclopamine } \\
\text { FGF10 } \\
\end{array}$ & $\begin{array}{c}1 \% \text { B27 } \\
\pm \text { Exendin } 4 \\
\pm \text { DAPT }\end{array}$ & $\begin{array}{c}1 \% \mathrm{~B} 27 \\
\pm \text { Exendin } 4 \\
\pm \mathrm{IGF}-1 \\
\pm \mathrm{HGF} \\
\end{array}$ & \\
\hline \multirow[b]{2}{*}{ Kroon et al., 2008} & Step 1 & Step 2 & Step 3 & Step 4 & Step 5 & & \\
\hline & $\begin{array}{c}\text { Activin A } \\
\text { Wnt3A }\end{array}$ & $\begin{array}{l}0.2 \% \text { FBS } \\
\text { Activin A }\end{array}$ & $\begin{array}{c}2 \% \text { FBS } \\
\text { KGF }\end{array}$ & $\begin{array}{c}1 \% \text { B27 } \\
\text { Retinoic Acid } \\
\text { Cyclopamine } \\
\text { Noggin } \\
\end{array}$ & $1 \%$ B27 & & \\
\hline \multirow[b]{2}{*}{ Chen et al., 2009} & Step 1 & Step 2 & Step 3 & Step 4 & Step 5 & Step 6 & Step 7 \\
\hline & $\begin{array}{c}\text { Activin A } \\
\text { Wnt3A }\end{array}$ & $\begin{array}{c}0.2 \% \text { FBS } \\
\text { Activin A }\end{array}$ & $\begin{array}{c}2 \% \text { FBS } \\
\text { FGF10 } \\
\text { KAAD-CYC } \\
\end{array}$ & $\begin{array}{c}1 \% \text { B27 } \\
\text { Retinoic Acid } \\
\text { FGF10 } \\
\text { KAAD-CYC } \\
\end{array}$ & $\begin{array}{l}1 \% \text { B27 } \\
\text { FGF10 } \\
\text { ILV }\end{array}$ & $\begin{array}{c}1 \% \mathrm{~B} 27 \\
\text { Exendin } 4 \\
\text { DAPT }\end{array}$ & $\begin{array}{c}1 \% B 27 \\
\text { HGF } \\
\text { IGF-1 } \\
\end{array}$ \\
\hline \multirow[b]{2}{*}{ Thatava et al., 2011} & & & Step 2 & Step 3 & Step 4 & Step 5 & Step 6 \\
\hline & $\begin{array}{r}\text { Activin A } \\
\text { Wint3A }\end{array}$ & $\begin{array}{l}0.2 \% \text { FBS } \\
\text { Activin A }\end{array}$ & $\begin{array}{l}2 \% \text { FBS } \\
\text { FGF10 } \\
\text { Cyclopamine }\end{array}$ & $\begin{array}{c}\text { B27 } \\
\text { FGF10 } \\
\text { Cyclopamine } \\
\text { Retinoic Acid } \\
\end{array}$ & $\begin{array}{c}\text { B27 } \\
\text { FGF10 } \\
\text { ILV } \\
\text { GLP-1 }\end{array}$ & $\begin{array}{c}\text { B27 } \\
\text { DAPT } \\
\text { GLP-1 }\end{array}$ & $\begin{array}{c}\text { B27 } \\
\text { HGF } \\
\text { GLP-1 } \\
\text { IGF-1 } \\
\end{array}$ \\
\hline \multirow[b]{2}{*}{ Jiang et al., 2007} & Step 1 & Step 2 & & Step 3 & Step 4 & Step 5 & Step 6 \\
\hline & & Activin A & & Retinoic Acid & $\mathrm{bFGF}$ & $\begin{array}{c}\text { bFGF } \\
\text { Nicotinamide }\end{array}$ & \\
\hline \multirow[b]{2}{*}{ Kunisada et al, 2011} & Step 1 & Step 2 & & Step 3 & Step 4 & & \\
\hline & $\begin{array}{c}2 \% \text { FBS } \\
\text { Activin A } \\
\text { CHIR99021 }\end{array}$ & $\begin{array}{r}2 \% \text { FBS } \\
\text { Activin A }\end{array}$ & & $\begin{array}{c}1 \% \text { B27 } \\
\text { Retinoic Acid } \\
\text { Dorsomorphin } \\
\text { SB431542 }\end{array}$ & $\begin{array}{c}1 \% \text { B27 } \\
\text { Forskolin } \\
\text { Nicotinamide } \\
\text { Dexamethasone } \\
\text { ALK5 inhibitor II } \\
\end{array}$ & & \\
\hline \multirow[b]{2}{*}{ Rezania et al., 2011} & Step 1 & & Step 2 & Step 3 & Step 4 & Step 5 & Step 6 \\
\hline & $\begin{array}{c}2 \% \text { BSA } \\
\text { Activin A } \\
\text { Wint3A } \\
\text { bFGF }\end{array}$ & & $\begin{array}{c}2 \% \text { BSA } \\
\text { FGF7 } \\
\text { Cyclopamine }\end{array}$ & $\begin{array}{c}\text { B27 } \\
\text { FGF7 } \\
\text { KAAD-CYC } \\
\text { Noggin } \\
\text { Retinoic Acid } \\
\end{array}$ & $\begin{array}{c}\text { B27 } \\
\text { ALK5 inhibitor II } \\
\text { DAPT } \\
\text { Noggin } \\
\text { Retinoic Acid } \\
\end{array}$ & $\begin{array}{c}\text { B27 } \\
\text { ALK5 inhibitor II }\end{array}$ & $\frac{\mathrm{slep} 0}{\mathrm{~B} 27}$ \\
\hline \multirow{3}{*}{ Shim et al., 2007} & Step 1 & Step 2 & & Step 3 & Step 4 & & \\
\hline & $20 \%$ FBS & Activin $\mathrm{A}$ & & Retinoic Acid & $\begin{array}{c}\text { ITS } \\
\text { Fibronectin } \\
\end{array}$ & & \\
\hline & (Embryoid body & & & & (Aggregates) & & \\
\hline \multirow[b]{2}{*}{ Nostro et al., 2011} & Step 1 & & Step 2 & Step 3 & Step 4 & & \\
\hline & $\begin{array}{c}\text { Activin A } \\
\text { BMP4 } \\
\text { bFGF } \\
\text { VEGF } \\
\end{array}$ & & FGF10 & $\begin{array}{c}\text { B27 } \\
\text { Noggin } \\
\text { KAAD-CYC } \\
\text { Retinoic Acid }\end{array}$ & B27 & & \\
\hline
\end{tabular}

Fig. 4. Methods for obtaining pancreatic $\beta$-cells from human ES/iPS cells. The steps of each protocol are aligned based on the use of cytokines, low molecular weight compounds, and supplements for the culture medium. Activin and retinoic acid are denoted by red and blue letters, respectively. Since the protocols reported by Shin et al., and Nostro et al., contain the steps to treat the cells after formation of embryoid bodies, notes are provided in parentheses. FBS, fetal bovine serum; FGF, fibroblast growth factor; DAPT, N-(N-((3,5-Difluorophenyl)acetyl)-L-alanyl)-L-phenylglycine tert-butyl ester; IGF, insulin-like growth factor; HGF, hepatocyte growth factor; KGF, keratinocyte growth factor; KAAD-CYC, 3-Keto-N-(aminoethyl-aminocaproyl-dihydrocinnamoyl) cyclopamine, ILV, (-)-Indolactam V; GLP, glucagon-like peptide; BMP, bone morphogenetic protein; VEGF, vascular endothelial growth factor. 
selectively inducing ES cells to differentiate into pancreatic $\beta$-cells (Lumelsky et al., 2001; Soria 2001; Blyszczuk et al., 2004), but research on human ES cells and iPS cells has now become the mainstream. Nevertheless, mouse ES cells have the advantages of easy genetic modification and conversion to cell lines, and are suitable for detailed analysis of differentiation mechanisms (Marchand et al., 2009). Because the findings obtained with mouse ES cell-derived cells can be easily translated into animal experiments, their importance to basic research remains unchallenged.

Numerous methods of inducing human ES cells to differentiate into insulin-producing cells have been reported (Fig. 4). Using activin to induce the differentiation of undifferentiated ES cells into endoderm and induction of pancreatic differentiation by combining retinoic acid with another factor are important elements that are common to almost all of the methods (Fig. 4) (D'Amour et al., 2006; Jiang et al., 2007; Kroon et al., 2008; Chen et al., 2009; Thatava et al., 2011). Differentiation of glucagon-producing cells by a similar method has also been reported (Rezania et al., 2011). It is possible to induce pancreatic differentiation of mouse EBSs by simultaneous stimulation with activin and retinoic acid (Nakanishi et al., 2007), but it seems necessary to treat human ES cells with these factors sequentially. Treatment with activin and retinoic acid has also been performed separately in studies on inducing human ES cells to differentiate via formation of EBs (Shim et al., 2007; Nostro et al., 2011). This difference between humans and mice seems likely to be attributable to the differing embryonic stages when human and mouse ES cells originate, as mentioned above. It would be helpful to conduct studies with mouse EpiSCs to confirm this point.

Because of differences in properties among human ES cell lines, it has been pointed out that it is necessary to find lines that easily show pancreatic differentiation (Osafune et al., 2008).

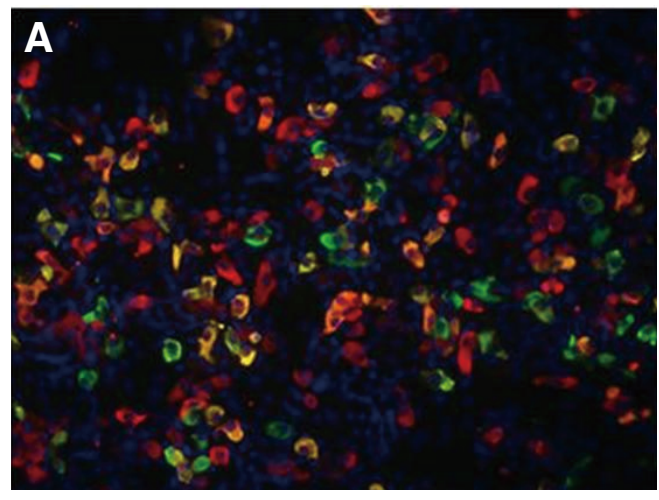

B

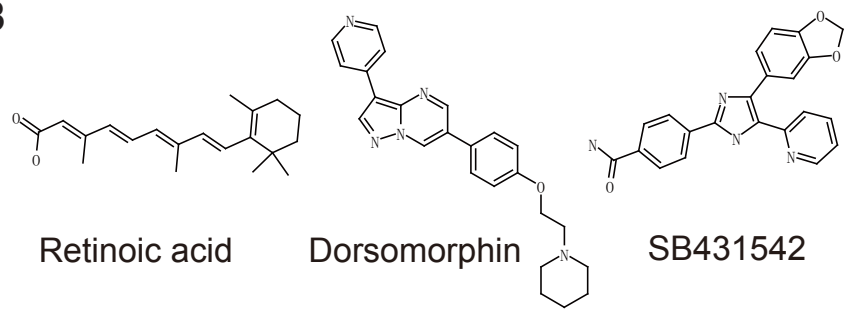

Fig. 5. Pancreatic endocrine cells prepared from human iPS cells. (A) Pancreatic endocrine cells were differentiated from human iPS cells using the method reported by Kunisada et al. Insulin (red), glucagon (green) and nuclei (blue) were identified by immunofluorescent staining. (B) The low molecular weight compounds used for pancreatic differentiation.
Kunisada et al., recently developed a method of inducing human iPS cells to differentiate into insulin-producing cells (Fig. 5) by screening for low molecular compounds to stimulate each stage of differentiation (e.g., by combining them with activin, retinoic acid, etc.) (Kunisada et al., 2012). The special feature of their method is that insulin-producing cells are obtained with similar efficiency when different human iPS cell lines are used. Its versatility has been confirmed with multiple iPS cell lines that differed in terms of donor age, gender, and reprogramming method, but no studies have yet been carried out on human ES cells. Besides insulin, cells that produced glucagon, somatostatin, and ghrelin were observed among the pancreatic endocrine cells induced by this method, but no cells producing PP were detected. The unevenness of PP cell distribution in the pancreas was mentioned above, and it is possible that induction of tissue corresponding to the left lobe of the pancreas (which contains PP cells) may require different signals.

It has been reported that it is possible to regulate pancreatic differentiation with low molecular weight compounds like histone deacetylase (HDAC) inhibitors (Haumaitre et al., 2009), and such compounds have been reported to be effective for increasing the efficiency of differentiating human ES cells and iPS cells into insulin-producing cells. Chen et al., reported that (-)-indolactam $\mathrm{V}$ was a compound that efficiently induced human ES cells to differentiate into PDX1-expressing cells (Chen et al., 2009). In the method described by Kunisada et al., PDX1 expression was induced when SOX17-positive endodermal cells were exposed to retinoic acid and dorsomorphin (a BMP type I receptor inhibitor), while differentiation proceeded as far as NGN3-positive pancreatic endocrine precursor cells when SB431542 (a TGF $\beta$ type I receptor inhibitor) was added at the same time (Fig. 5) (Kunisada et al., 2012). Moreover, use of ALK5 inhibitor II has been reported in a pancreatic $\alpha$-cell differentiation system. Because Hedgehog expression is inhibited in the pancreatic primordium compared with surrounding organs, two Hedgehog signal inhibitors (cyclopamine and KADD-cyclopamine) have been used in many other methods (D'Amour et al., 2006, 2007; Kroon et al., 2008; Chen et al., 2009; Thatava et al., 2011; Nostro et al., 2011; Rezania et al., 2011).

A detailed function comparison between human pancreatic $\beta$-cells and insulin-producing cells that had been differentiated from human ES cells was reported (Basford et al., 2011). Gene expression profiling revealed that genes related to $\beta$-cell functions, such as glucose sensing and exocytosis, were expressed in both types of cells, as were specific transcriptional factors involved in the pancreatic endocrine system. However, the insulin-producing cells differentiated in vitro also expressed glucagon and glucose responsiveness was not detected. Such features resembled those of undifferentiated endocrine cells that emerge during embryonic development. Nevertheless, the finding that the insulin-producing cells differentiated in vitro were not homogeneous suggests the possibility of obtaining cells that would be useful for cell therapy by purification based on differences of their properties (Basford et al., 2011). Moreover, long-term survival and functioning in vivo were reported when pancreatic islet-like structures were prepared from insulin-producing cells that had been differentiated from human ES cells and transplanted into animals with diabetes (Eshpeter et al., 2008). The ability of ES cells and iPS cells to differentiate into insulin-producing cells has been verified by many reports. However, no routine method for inducing functional maturation in vivo or in vitro has been established so far. 


\section{Differentiation of somatic stem cells into pancreatic $\beta$-cells}

There are some problems with human ES cells, such as changes in the number of chromosomes as a result of repeated subculture, that do not arise with mouse ES cells. There is also the ethical problem of using fertilized eggs in the establishment of human ES cells. Since fertilized eggs are not required, the ethical hurdle is low for human iPS cells. However, standardization of iPS is more difficult than for human ES cells, because of diversity in the efficiency and accuracy of reprogramming. Since the possibility of ES cells or iPS cells forming teratomas has been pointed out, it seems necessary to eliminate undifferentiated cells as completely as possible. This is always a problem with ES/iPS cells that are produced artificially. On the other hand, inducing endocrine differentiation has been attempted by transdifferentiation of acinar cells and pancreatic duct cells. Zhou et al., showed that it is possible to reprogram acinar cells to become pancreatic $\beta$-cells in vivo by introducing 3 transcriptional factors (NGN3, PDX1, and MAFA) (Zhou etal., 2008). It has also been reported that transdifferentiation of $\alpha$-cells into $\beta$-cells can be done in vivo (Courtney et al., 2011). These artificial transdifferentiation methods also appear to have the same problem as iPS cells in relation to safety associated with reprogramming, so investigation of the use of endogenous stem cells is also very important.

Before ES cells or iPS cells were discovered, primary culture of pancreatic islets and other pancreatic cells was performed (Campbell, et al., 1985; Bonner-Weir et al., 2004; Baeyens and Bouwens, 2008) to obtain cell lines (Itkin-Ansari et al., 2003) and precursor cells with the ability to proliferate during embryonic development (Xia et al., 2009), and the use of such cells in regenerative medicine for diabetes was investigated. However, none of these methods ever reached the point of practical application. Studies of umbilical cord blood or bone marrow-derived stem cells, pancreatic duct epithelial cells, acinar cells, and hepatocytes have been widely performed (Aguayo-Mazzucato and Bonner-Weir, 2010), and attempts to obtain stem cells from the pancreas itself are continuing (Jiang and Moraham, 2011).

A blood glucose-lowering effect was reported when bone marrow-derived stem cells were administered to animals with diabetes (Hess et al., 2003). Improvement of pathology was reported when mouse bone marrow-derived stem cells were differentiated into insulin-producing cells in vitro and then injected into diabetic animals (Tang et al., 2004). Many aspects of the mechanism by which bone marrow-derived cells differentiate directly into pancreatic cells are unknown, but there have been various reports about improvement of diabetes and recovery of pancreatic $\beta$-cell function as a result of treatment with bone marrow-derived stem cells. Therefore, research on stem cells as a method of treating diabetes is continuing (Ciceri and Piemonti, 2010). Transdifferentiation into insulin-producing cells after introduction of the PDX1 gene into human bone marrow-derived mesenchymal stem cells has also been reported (Li et al., 2007). On the other hand, it was reported that the pancreatic $\beta$-cells of recipients of bone marrow cell transplantation did not regenerate in response to stimulation (Hamamoto et al., 2010). In addition to bone marrow-derived mesenchymal stem cells, adipose-tissue derived mesenchymal stem cells have also been reported to display multipotent differentiation into a variety of tissues (Zuk et al., 2002). Moreover, it has been reported that human adipose-tissue derived mesenchymal stem cells can be induced to differentiate into pancreatic hormone-expressing cells in vitro (Timper et al., 2006). Kajiyama et al., recently performed intravenous injection of adipose-tissue derived stem cells into which the PDX1 gene had been introduced, and showed that these cells colonized the pancreas and differentiated into insulinproducing cells (Kajiyama et al., 2010). As shown by research at the organogenetic stage, pancreatic endocrine precursor cells lose their ability to proliferate once NGN3 is expressed (Castaing et al., 2005). Thus, introduction of PDX1 alone (without NGN3 or MAFA) may be effective. Since verification by transplantation is impossible in humans, it would seem necessary to conduct transplantation studies in experimental animals and to proceed with this research cautiously before attempting clinical application.

More recently, it was reported that it is possible to induce insulin expression by cells from outside the pancreatic lineage, such as dental pulp, umbilical cord, amniotic fluid, and neural stem cells, even without pancreatic cell gene transfer (Govindasamy et al., 2011; Kadam and Bhonde, 2010; Trovato et al., 2009; Kuwabara et al., 2011). Even prior to these studies, it was reported that cells expressing the neural stem cell marker nestin can be differentiated into insulin-producing cells (Lumelsky et al., 2001), although the possibility of this result being an artifact was raised (Hansson et al., 2004). However, a recent study showed that the cytokine Wnt3, which is secreted in a paracrine manner by neural stem cells, induces insulin expression via NeuroD and is inhibited by IGFBP-4 (Kuwabara et al., 2011). Since neural cells and pancreatic $\beta$-cells are similar in various respects (Arntfield and van der Kooy, 2011), it seems that neural stem cells may also be a candidate source of insulin-expressing cells.

\section{Future prospects and challenges}

It is necessary to pay meticulous attention to quality control when cells are used for medical purposes. While human iPS cells have the advantage of being prepared from the patients themselves (Maehr et al., 2009), it is still important to draw up criteria for cells that can be used clinically, such as the extent of reprogramming. It might be more practical to bank cells, including human ES cells, for which safety has been confirmed and which show tissue compatibility to some extent (Nakatsuji 2010). After stem cells are isolated for cultivation, components of animal origin in the media must be removed as much as possible. In addition to serum depletion, attention should be paid to components such as the extracellular matrix, culture medium supplements, and enzymes used for cell harvesting. It would be preferable for clinical grade cells, from which various possible contaminants have been eliminated, to be available for both basic research and clinical research. In addition, because there is concern about tumor formation as a result of contamination by cells that have not been adequately differentiated, it also seems necessary to establish criteria for cell purity. The current status of potential cell-based therapies for type I diabetes is summarized in Table 1.

Since pancreatic islet transplantation is currently performed intrahepatically by intravenous infusion into the portal vein, the burden on the patient is low. However, due to many factors, including islet quality, poor oxygen supply, and induction of an immune response, the survival rate of pancreatic islets after transplantation is not high enough, so islet transplantation is not very efficient. 
Since the quality of pancreatic islets depends on the health of the donor, the donor's medications, and the method of islet preparation, it is particularly difficult to evaluate the likely outcome in individual clinical cases (Berney and Toso, 2006). For this reason, transplantation usually has to be done more than once. A study conducted in rats suggested that transplantation into the pancreas had a greater therapeutic effect on diabetes, requiring fewer islets than infusion into the portal vein for hepatic transplantation (Stagner et al., 2008). However, the high invasiveness of intrapancreatic transplantation and the risk of causing pancreatitis have been pointed out as problems that could inhibit clinical application (Rajab, 2010). Other sites for transplantation, including the spleen and peritoneum, have also been tried, but there are pros and cons for each of them and an optimal site for islet transplantation has not been established (Rajab, 2010). By utilizing devices that achieve immunological isolation by encapsulation, pancreatic islets or $\beta$ cells of animal origin can also be transplanted, but their long-term use would seem difficult at present.

As reported by Kajiyama et al., if injecting cells into a peripheral vein for colonization and differentiation in the pancreas were possible in humans, the issue of the transplantation site could be solved (Kajiyama et al., 2010). It has long been known that mesenchymal stem cells enter the bloodstream and home to sites of injury, but the mechanisms of their homing and migration through the vessel walls have been unclear (Sordi, 2009). However, cross-talk by CXCR4-CXCL12 and CX3CR1-CX3CL1 in bone marrow-derived mesenchymal stem cells and pancreatic islets has been found to be involved, and mesenchymal stem cells expressing these receptors have been isolated from human pancreatic islets (Sordi et al., 2005). Thus, utilizing a delivery mechanism that already exists in the body is an advantage of mesenchymal stem cells that ES/ iPS cells do not possess. In order to apply these cells clinically, however, extensive verification experiments would be necessary in order to be able to guarantee safety and effectiveness. Nevertheless, since the process only involves transfer of a single gene into autogenous cells, quality control seems to be simple in comparison with monitoring cells that have been in long-term culture. Assessing methods of introducing gene expression vectors that are not integrated into chromosomes and substitution by proteins and low molecular compounds are tasks for future studies.

Utilization of low molecular weight compounds to regulate cell differentiation is useful and convenient. As described in the reviews by Lyssiotis et al., and Li et al., many compounds can be useful for regulating differentiation and for reprogramming cells (Lyssiotis et al., 2011; Li et al., 2011). The mechanisms of action of some compounds that regulate stem cell differentiation are already known, and the target molecules have been identified for some others. Compounds like the latter are particularly linked to elucidating new cell regulation mechanisms, including the induction of differentiation. Future studies of such compounds could lead to the development of drugs that stimulate organ regeneration by acting on endogenous stem cells. Pancreatic $\beta$-cell hyperplasia, proliferation, and neogenesis may occur in relation to pregnancy, obesity, and pancreatic $\beta$-cell damage, but these processes are reported to differ between humans and rodents (Rieck and Kaestner, 2010), so it will be necessary to proceed very carefully with research. Pancreatic $\beta$-cell proliferation has not been observed in humans with pregnancy or type 2 diabetes (Rieck and Kaestner, 2010). If it is possible to find a factor that inhibits human pancreatic
TABLE 1

\section{SUMMARY OF POSSIBLE CELL-BASED THERAPIES FOR TYPE I DIABETES}

\begin{tabular}{|c|c|c|c|c|c|}
\hline & \multicolumn{2}{|r|}{ Islets } & \multicolumn{3}{|c|}{ Stem Cells } \\
\hline & islet & $\begin{array}{c}\text { encapsulated } \\
\text { islet (xenogenic) }\end{array}$ & ES cells & iPS cells & $\begin{array}{l}\text { somatic } \\
\text { stem cells }\end{array}$ \\
\hline Current status & Clinical & ${ }^{*}$ Phase II & Basic & Basic & Basic \\
\hline Quality control & difficult & possible & possible & possible & possible \\
\hline Banking & impossible & not needed & difficult & possible & possible \\
\hline Manufacturing & impossible & possible & possible & possible & possible \\
\hline Autocytotherapy & impossible & not applicable & impossible & possible & possible \\
\hline Tumorigenicity & No & No & Yes & $\begin{array}{l}\text { To be } \\
\text { improved }\end{array}$ & No \\
\hline $\begin{array}{l}\text { Application to } \\
\text { drug discovery }\end{array}$ & possible & not applicable & possible & suitable & possible \\
\hline
\end{tabular}

*Living Cell Technologies (LCT, New Zealand) is conducting a Phase Il clinical trial to study the safety and effectiveness of transplanting encapsulated porcine islet cells as a treatment for type 1 diabetes.

$\beta$-cell proliferation, like the discovery of reprogramming factor for iPS cell generation, we think that low molecular weight drugs for pancreatic regeneration might also be developed.

The availability of mature and functional human pancreatic $\beta$-cells is very important, not only for cell therapy, but also for the development of drugs to treat diabetes. Pancreatic islets have already been used to conduct research, but as with pancreatic islet transplantation, damage as a result of harvesting (Kin et al., 2007) is a concern. Moreover, there have been many reports regarding primary culture, but unfortunately a practical protocol has never been established for culturing islets that are functionally intact. Even though many cell lines are available, it seems to be difficult to establish pancreatic $\beta$-cells that properly retain their functions in vitro. Cell lines like INS-1 (Asfari et al., 1992) and MIN6 (Miyazaki et al., 1990) have been established from rodents, and have made a large contribution to pancreatic $\beta$-cell research. After various attempts to establish human cell lines from endocrine tumors like insulinomas over a long period, EndoC- $\beta \mathrm{H} 1$ cells were recently reported as a functional human pancreatic $\beta$-cell line (Ravassard et al., 2011). However, this only emphasizes that it is very difficult to culture human pancreatic $\beta$-cells for use as a drug discovery tool. The rise in healthcare costs as a result of the increase in diabetic patients will cause economic problems in the near future. Therefore, the prevention and cure of diabetes are extremely important from a healthcare economic perspective as well (Boqaert and Schrier, 2011). Moreover, insulin has other important functions besides its role in blood glucose regulation, so the preservation of basal insulin secretion is also required (Niswender, 2011). Restoring or maintaining the function of residual pancreatic $\beta$-cells is expected to reduce healthcare costs as well as preventing the progression of diabetes. Accordingly, we need human pancreatic $\beta$-cells prepared in vitro from undifferentiated cells as a drug discovery tool. The discovery and development of antidiabetic drugs is continuing with a focus on preserving or restoring the function of pancreatic islets that have been damaged by a variety of causes, including hyperglycemia.

\section{Conclusion}

Inducing the differentiation of pancreatic $\beta$-cells in vitro has been achieved as a result of various avenues of research. Selective induction of undifferentiated stem cells into cells that perform special 
functions such as pancreatic $\beta$-cells is very interesting from an academic standpoint. However, patients are looking forward to the establishment of a method of inducing pancreatic $\beta$-cell differentiation for the treatment of diabetes. As a result of continuing efforts, progress is being made in research aiming at the development of cell therapy for diabetes instead of pancreatic islet transplantation. This review has covered recent developments as far as possible. We hope it will be helpful for understanding which problems have been solved already and which problems remain to be tackled.

\section{References}

AGUAYO-MAZZUCATO, C, and BONNER-WEIR, S. (2010) Stem cell therapy for type 1 diabetes mellitus. Nat. Rev. Endocrinol. 2: 139-148.

ARNTFIELD, M.E., and VAN DER KOOY, D. (2011) b-Cell evolution: How the pancreas borrowed from the brain: The shared toolbox of genes expressed by neural and pancreatic endocrine cells may reflect their evolutionary relationship. Bioessays 33: 582-587.

ASASHIMA, M., ITO, Y., CHAN, T., MICHIUE, T., NAKANISHI, M., SUZUKI, K., HITACHI, K., OKABAYASHI, K., KONDOW, A., and ARIIZUMI, T. (2009) In vitro organogenesis from undifferentiated cells in Xenopus. Dev. Dyn. 238: 1309-1320.

ASFARI, M., JANJIC, D., MEDA, P., LI, G., HALBAN, P.A., and WOLLHEIM, CB. (1992) Establishment of 2-mercaptoethanol-dependent differentiated insulin-secreting cell lines. Endocrinology 130: 167-178.

BAEYENS, L., and BOUWENS, L. (2008) Can beta-cells be derived from exocrine pancreas? Diabetes Obes. Metab. 10 Suppl 4: 170-178.

BASFORD, C.L., PRENTICE, K.J., HARDY, A.B., SARANGI, F., MICALLEF, S.J., LI, X., GUO, Q., ELEFANTY, A.G., STANLEY, E.G., KELLER, G., ALLISTER, E.M., NOSTRO, M.C., and WHEELER, M.B. (2012) The functional and molecular characterisation of human embryonic stem cell-derived insulin-positive cells compared with adult pancreatic beta cells. Diabetologia 55: 358-371.

BERNEY, T., and TOSO, C. (2006) Monitoring of the islet graft. Diabetes Metab. 32: 503-512.

BLYSZCZUK, P., ASBRAND, C., ROZZO, A., KANIA, G., ST-ONGE. L., RUPNIK, M, and WOBUS, A.M. (2004) Embryonic stem cells differentiate into insulin-producing cells without selection of nestin-expressing cells. Int. J. Dev. Biol. 48: 1095-1104.

BOGAERT, Y.E., and SCHRIER, R.W. (2011) Into the future: prevention of diabetes. Contrib. Nephrol. 170: 256-263.

BONNER-WEIR, S., TOSCHI, E., INADA, A., REITZ, P., FONSECA, S.Y., AYE, T., and SHARMA, A. (2004) The pancreatic ductal epithelium serves as a potential pool of progenitor cells. Pediatr. Diabetes 5 Suppl 2: 16-22.

BRENNAND, K., HUANGFU, D., MELTON, D. (2007) All beta cells contribute equally to islet growth and maintenance. PLoS Biol. 5:e163.

BRISSOVA, M., FOWLER, M.J., NICHOLSON, W.E., CHU, A., HIRSHBERG, B., HARLAN, D.M., and POWERS, A.C. (2005) Assessment of human pancreatic islet architecture and composition by laser scanning confocal microscopy. J. Histochem. Cytochem. 53: 1087-1097.

BUEHR, M., MEEK, S., BLAIR, K., YANG, J., URE, J., SILVA, J., MCLAY, R., HALL, J., YING, QL., and SMITH, A. (2008) Capture of authentic embryonic stem cells from rat blastocysts. Cell 135: 1287-1298.

CAMPBELL, I.L., COLMAN, P.G., and HARRISON, L.C. (1985) Adult human pancreatic islet cells in tissue culture: function and immunoreactivity. J. Clin. Endocrinol. Metab. 61: 681-685.

CASTAING, M., DUVILLIÉ, B., QUEMENEUR, E., BASMACIOGULLARI, A., and SCHARFMANN, R. (2005) Ex vivo analysis of acinar and endocrine cell development in the human embryonic pancreas. Dev. Dyn. 234: 339-345

CHEN, S., BOROWIAK, M., FOX, J.L., MAEHR, R., OSAFUNE, K., DAVIDOW, L., LAM, K., PENG, L.F., SCHREIBER, S.L., RUBIN, L.L., and MELTON, D. (2009) A small molecule that directs differentiation of human ESCs into the pancreatic lineage. Nat. Chem. Biol. 5: 258-265.

CICERI, F., and PIEMONTI, L. (2010) Bone marrow and pancreatic islets: an old story with new perspectives. Cell Transplant. 19: 1511-1522.

CRIVELLATO, E., NICO, B., and RIBATTI, D. (2007) Contribution of endothelial cells to organogenesis: a modern reappraisal of an old Aristotelian concept. J.
Anat. 211: 415-427.

COURTNEY, M., PFEIFER, A., AL-HASANI, K., GJERNES, E., VIEIRA, A., BENOTHMAN, N., and COLLOMBAT, P. (2011) In vivo conversion of adult a-cells into b-like cells: a new research avenue in the context of type 1 diabetes. Diabetes Obes. Metab. 13 Suppl 1: 47-52.

D'AMOUR, K.A., BANG, A.G., ELIAZER, S., KELLY, O.G., AGULNICK, A.D., SMART, N.G., MOORMAN, M.A., KROON, E., CARPENTER, M.K., and BAETGE, E.E. (2006) Production of pancreatic hormone-expressing endocrine cells from human embryonic stem cells. Nat. Biotechnol. 24: 1392-1401.

DAILEY, G. (2011) Overall mortality in diabetes mellitus: where do we stand today? Diabetes Technol. Ther. 13 Suppl 1:S65-74.

EMAMAULLEE, J.A., and SHAPIRO, A.M.J. (2008) Islet cell transplantation. In Principles of regenerative medicine (Atala, A. et al., Eds.). Academic Press, Burlington, MA, pp794-811.

ESHPETER, A., JIANG, J., AU, M., RAJOTTE, R.V., LU, K., LEBKOWSKI, J.S. MAJUMDAR, A.S., and KORBUTT, G.S. (2008) In vivo characterization of transplanted human embryonic stem cell-derived pancreatic endocrine islet cells. Cell Prolif. 41: 843-858.

GERSELL, D.J., GINGERICH, R.L., and GREIDER, M.H. (1979) Regional distribution and concentration of pancreatic polypeptide in the human and canine pancreas. Diabetes 28: 11-15.

GOVINDASAMY, V., RONALD, V.S., ABDULLAH, A.N., NATHAN, K.R., ABAZIZ, Z.A., ABDULLAH, M., MUSA, S., KASIM, N.H., and BHONDE, R.R. (2011) Differentiation of dental pulp stem cells into islet-like aggregates. J. Dent. Res. 90: 646-652.

GREINER, T.U., KESAVAN, G., STÅHLBERG, A., and SEMB, H. (2009) Rac1 regulates pancreatic islet morphogenesis. BMC Dev. Biol. 9: 2.

GU, Q., HAO, J., ZHAO, X.Y., LI, W., LIU, L., WANG, L., LIU, Z.H., and ZHOU, Q. (2012) Rapid conversion of human ESCs into mouse ESC-like pluripotent state by optimizing culture conditions. Protein Cell 3: 71-79.

GUO, T. and HEBROK, M. (2009) Stem cells to pancreatic beta-cells: new sources for diabetes cell therapy. Endocr. Rev. 30: 214-227.

HAMAMOTO, Y., AKASHI, T., INADA, A., BONNER-WEIR, S., and WEIR, G.C. (2010) Lack of evidence for recipient precursor cells replenishing b-cells in transplanted islets. Cell Transplant. 19: 1563-1572.

HANSSON, M., TONNING, A., FRANDSEN, U., PETRI, A., RAJAGOPAL, J., ENGLUND, M.C., HELLER, R.S., HÅKANSSON, J., FLECKNER, J., SKÖLD, H.N., MELTON, D., SEMB, H., and SERUP, P. (2004) Artifactual insulin release from differentiated embryonic stem cells. Diabetes 53: 2603-2609.

HAUMAITRE, C., LENOIR, O., and SCHARFMANN, R. (2009) Directing cell differentiation with small-molecule histone deacetylase inhibitors: the example of promoting pancreatic endocrine cells. Cell Cycle 8: 536-544.

HELLER, R.S. (2010) The comparative anatomy of islets. Adv. Exp. Med. Biol. 654 21-37.

HESS, D., LI, L., MARTIN, M., SAKANO, S., HILL, D., STRUTT, B., THYSSEN, S., GRAY, D.A., and BHATIA, M. (2003) Bone marrow-derived stem cells initiate pancreatic regeneration. Nat. Biotechnol. 21: 763-770.

IN'T VELD, P, and MARICHAL, M. (2010) Microscopic anatomy of the human islet of Langerhans. Adv. Exp. Med. Biol. 654: 1-19.

ITKIN-ANSARI, P., GERON, I., HAO, E., DEMETERCO, C., TYRBERG, B., and LEVINE, F. (2003) Cell-based therapies for diabetes: progress towards a transplantable human beta cell line. Ann. N. Y. Acad. Sci. 1005: 138-147.

JIANG, F.X., and MORAHAN, G. (2011) Pancreatic Stem Cells: From Possible to Probable. Stem Cell Rev. (doi: 10.1007/s12015-011-9333-8)

JIANG, J., AU, M., LU, K., ESHPETER, A., KORBUTT, G., FISK, G., and MAJUMDAR, A.S. (2007) Generation of insulin-producing islet-like clusters from human embryonic stem cells. Stem Cells 25: 1940-1953.

JIANG, W., SHI, Y., ZHAO, D., CHEN, S., YONG, J., ZHANG, J., QING, T., SUN, X. ZHANG, P., DING, M., LI, D., and DENG, H. (2007) In vitro derivation of functional insulin-producing cells from human embryonic stem cells. Cell Res. 17: 333-344

KADAM, S.S., and BHONDE, R.R. (2010) Islet neogenesis from the constitutively nestin expressing human umbilical cord matrix derived mesenchymal stem cells. Islets 2: 112-120

KAJIYAMA, H., HAMAZAKI, T.S., TOKUHARA, M., MASUI, S., OKABAYASHI, K., OHNUMA, K., YABE, S., YASUDA, K., ISHIURA, S., OKOCHI, H., and ASASHIMA, M. (2010) Pdx1-transfected adipose tissue-derived stem cells differentiate into 
insulin-producing cells in vivo and reduce hyperglycemia in diabetic mice. Int. J. Dev. Biol. 54: 699-705.

KIN, T., JOHNSON, P.R., SHAPIRO, A.M., and LAKEY, J.R. (2007) Factors influencing the collagenase digestion phase of human islet isolation. Transplantation 83: 7-12.

KOBAYASHI, T., YAMAGUCHI, T., HAMANAKA, S., KATO-ITOH, M., YAMAZAKI, Y., IBATA, M., SATO, H., LEE, Y.S., USUI, J., KNISELY, A.S., HIRABAYASHI, M., and NAKAUCHI, H. (2010) Generation of rat pancreas in mouse by interspecific blastocyst injection of pluripotent stem cells. Cell 142: 787-799.

KROON, E., MARTINSON, L.A., KADOYA, K., BANG, A.G., KELLY, O.G., ELIAZER, S., YOUNG, H., RICHARDSON, M., SMART, N.G., CUNNINGHAM, J., AGULNICK, A.D., D'AMOUR, K.A., CARPENTER, M.K., and BAETGE, E.E. (2008) Pancreatic endoderm derived from human embryonic stem cells generates glucose-responsive insulin-secreting cells in vivo. Nat. Biotechnol. 26: 443-452.

KUNISADA, Y., TSUBOOKA-YAMAZOE, N., SHOJI, M., and HOSOYA, M. (2012) Small molecules induce efficient differentiation into insulin-producing cells from human induced pluripotent stem cells. Stem Cell Res. 8: 274-284.

KURISAKI, A., ITO, Y., ONUMA, Y., INTOH, A., and ASASHIMA, M. (2010) In vitro organogenesis using multipotent cells. Hum. Cell. 23: 1-14.

KUWABARA, T., KAGALWALA, M.N., ONUMA, Y., ITO, Y., WARASHINA, M., TERASHIMA, K., SANOSAKA, T., NAKASHIMA, K., GAGE, F.H., and ASASHIMA, M. (2011) Insulin biosynthesis in neuronal progenitors derived from adult hippocampus and the olfactory bulb. EMBO Mol. Med. 3: 742-754

LAMMERT, E., CLEAVER, O., and MELTON, D. (2001) Induction of pancreatic differentiation by signals from blood vessels. Science 294: 564-567.

LI, P., TONG, C., MEHRIAN-SHAI, R., JIA, L., WU, N., YAN, Y., MAXSON, R.E., SCHULZE, E.N., SONG, H., HSIEH, C.L., PERA, M.F., and YING, Q.L. (2008) Germline competent embryonic stem cells derived from rat blastocysts. Cell 135: 1299-1310.

LI, W., JIANG, K., and DING, S. (2012) A Chemical Approach to Controlling Cell Fate and Function. Stem Cells 30: 61-68.

LI, Y., ZHANG, R., QIAO, H., ZHANG, H., WANG, Y., YUAN, H., LIU, Q., LIU, D., CHEN, L., and PEI, X. (2007) Generation of insulin-producing cells from PDX-1 gene-modified human mesenchymal stem cells. J. Cell. Physiol. 211: 36-44.

LUMELSKY, N., BLONDEL, O., LAENG, P., VELASCO, I., RAVIN, R., and MCKAY, R. (2001) Differentiation of embryonic stem cells to insulin-secreting structures similar to pancreatic islets. Science 292: 1389-1394.

LYSSIOTIS, C.A., LAIRSON, L.L., BOITANO, A.E., WURDAK, H., ZHU, S., and SCHULTZ, P.G. (2011) Chemical control of stem cell fate and developmental potential. Angew. Chem. Int. Ed. Engl. 50: 200-242.

MADSEN, O.D. (2007) Pancreas phylogeny and ontogeny in relation to a 'pancreatic stem cell'. C. R. Biol. 330: 534-537.

MAEHR, R., CHEN, S., SNITOW, M., LUDWIG, T., YAGASAKI, L., GOLAND, R., LEIBEL, R.L., and MELTON, D.A. (2009) Generation of pluripotent stem cells from patients with type 1 diabetes. Proc. Natl. Acad. Sci. USA. 106: 15768-15773.

MARCHAND, M., SCHROEDER, I.S., MARKOSSIAN, S., SKOUDY, A., NĖGRE, D., COSSET, F.L,, REAL, P., KAISER, C., WOBUS, A.M., and SAVATIER, P. (2009) Mouse ES cells over-expressing the transcription factor NeuroD1 show increased differentiation towards endocrine lineages and insulin-expressing cells. Int. J. Dev. Biol. 53: 569-578.

MATSUMOTO, S (2011) Clinical allogenic and autologous islet cell transplantation: update. Diabetes Metab. J. 35: 199-206.

MIYAZAKI, J., ARAKI, K., YAMATO, E., IKEGAMI, H., ASANO, T., SHIBASAKI, Y., OKA, Y., and YAMAMURA K. (1990) Establishment of a pancreatic beta cell line that retains glucose-inducible insulin secretion: special reference to expression of glucose transporter isoforms. Endocrinology 127: 126-132.

MORIYA, N., KOMAZAKI, S., TAKAHASHI, S., YOKOTA, C., and ASASHIMA, M. (2000b) In vitro pancreas formation from Xenopus ectoderm treated with activin and retinoic acid. Dev. Growth Differ. 42: 593-602.

MORIYA, N., KOMAZAKI, S., and ASASHIMA, M. (2000a) In vitro organogenesis of pancreas in Xenopus laevis dorsal lips treated with retinoic acid. Dev. Growth Differ. 42: 175-185.

MURTAUGH, L.C. (2007) Pancreas and beta-cell development: from the actual to the possible. Development 134: 427-438.

NAKANISHI, M., HAMAZAKI, T.S., KOMAZAKI, S., OKOCHI, H., and ASASHIMA, M. (2007) Pancreatic tissue formation from murine embryonic stem cells in vitro. Differentiation 75: 1-11.
NAKATSUJI, N. (2010) Banking human pluripotent stem cell lines for clinical application? J. Dent. Res. 89: 757-758.

NICHOLS, J., and SMITH, A. (2009) Naive and primed pluripotent states. Cell Stem Cell 4: 487-492.

NISWENDER, K.D. (2011) Basal insulin: beyond glycemia. Postgrad. Med. 123:27-37

NOSTRO, M.C., SARANGI, F., OGAWA, S., HOLTZINGER, A., CORNEO, B., LI, X., MICALLEF, S.J., PARK, I.H., BASFORD, C., WHEELER, M.B., DALEY, G.Q., ELEFANTY, A.G., STANLEY, E.G., and KELLER, G. (2011) Stage-specific signaling through TGFb family members and WNT regulates patterning and pancreatic specification of human pluripotent stem cells. Development 138: 861-871.

OKAHARA, M., MORI, H., KIYOSUE, H., YAMADA, Y., SAGARA, Y., and MATSUMOTO, S. (2010) Arterial supply to the pancreas; variations and cross-sectional anatomy. Abdom. Imaging. 35: 134-142.

OKITA, K., MATSUMURA, Y., SATO, Y., OKADA, A., MORIZANE, A., OKAMOTO S., HONG, H., NAKAGAWA, M., TANABE, K., TEZUKA, K., SHIBATA, T., KUNISADA, T., TAKAHASHI, M., TAKAHASHI, J., SAJI, H., and YAMANAKA S. (2011) A more efficient method to generate integration-free human iPS cells. Nat. Methods 8: 409-412.

OLIVER-KRASINSKI, J.M., and STOFFERS, D.A. (2008) On the origin of the beta cell. Genes Dev. 22: 1998-2021.

OSAFUNE, K., CARON, L., BOROWIAK, M., MARTINEZ, R.J., FITZ-GERALD, C.S., SATO, Y., COWAN, C.A., CHIEN, K.R., and MELTON, D.A. (2008) Marked differences in differentiation propensity among human embryonic stem cell lines. Nat. Biotechnol. 26: 313-315.

PAN, F.C., and Wright, C, (2011) Pancreas organogenesis: from bud to plexus to gland. Dev. Dyn. 240: 530-565

PURI, S., and HEBROK, M. (2010) Cellular plasticity within the pancreas--lessons learned from development. Dev. Cell 18: 342-356.

RAJAB, A. (2010) Islet transplantation: alternative sites. Curr. Diab. Rep. 10:332-337.

RAVASSARD, P., HAZHOUZ, Y., PECHBERTY, S., BRICOUT-NEVEU, E., ARMANET, M., CZERNICHOW, P., and SCHARFMANN, R. (2011) A genetically engineered human pancreatic b cell line exhibiting glucose-inducible insulin secretion. J. Clin Invest. 121: 3589-3597.

REZANIA, A., RIEDEL, M.J., WIDEMAN, R.D., KARANU, F., AO, Z., WARNOCK G.L., and KIEFFER, T.J. (2011) Production of functional glucagon-secreting a-cells from human embryonic stem cells. Diabetes 60: 239-247.

RIECK, S., and KAESTNER, K.H. (2010) Expansion of beta-cell mass in response to pregnancy. Trends Endocrinol. Metab. 21: 151-158.

RIEDEL, M.J., ASADI, A., WANG, R., AO, Z., WARNOCK, G.L., and KIEFFER, T.J. (2012) Immunohistochemical characterisation of cells co-producing insulin and glucagon in the developing human pancreas. Diabetologia 55: 372-381.

RODRIGUEZ-DIAZ, R., ABDULREDA, M.H., FORMOSO, A.L., GANS, I., RICORDI, C., BERGGREN, P.O., and CAICEDO, A. (2011) Innervation patterns of autonomic axons in the human endocrine pancreas. Cell Metab. 14: 45-54.

SCHARFMANN, R. (2000) Control of early development of the pancreas in rodents and humans: implications of signals from the mesenchyme. Diabetologia 43: 1083-1092.

SERAFIMIDIS, I., HEXIMER, S., BEIS, D., and GAVALAS, A. (2011) G protein-coupled receptor signaling and sphingosine-1-phosphate play a phylogenetically conserved role in endocrine pancreas morphogenesis. Mol. Cell. Biol. 31: 4442-4453.

SHAPIRO, A.M., LAKEY, J.R., RYAN, E.A., KORBUTT, G.S., TOTH, E., WARNOCK, G.L., KNETEMAN, N.M., and RAJOTTE, R.V. (2000) Islet transplantation in seven patients with type 1 diabetes mellitus using a glucocorticoid-free immunosuppressive regimen. N. Engl. J. Med. 343: 230-238.

SHCHORS, K., SHCHORS, E., ROSTKER, F., LAWLOR, E.R., BROWN-SWIGART, L., and EVAN, G.I. (2006) The Myc-dependent angiogenic switch in tumors is mediated by interleukin 1beta. Genes Dev. 20: 2527-2538

SHIM, J.H., KIM, S.E., WOO, D.H., KIM, S.K., OH, C.H., MCKAY, R., and KIM, J.H. (2007) Directed differentiation of human embryonic stem cells towards a pancreatic cell fate. Diabetologia 50: 1228-1238.

SORDI, V. (2009) Mesenchymal stem cell homing capacity. Transplantation 87(9 Suppl):S42-45

SORDI, V., MALOSIO, M.L., MARCHESI, F., MERCALLI, A., MELZI, R., GIORDANO, T., BELMONTE, N., FERRARI, G., LEONE, B.E., BERTUZZI, F., ZERBINI, G., ALLAVENA, P., BONIFACIO, E., and PIEMONTI, L. (2005) Bone marrow mesenchymal stem cells express a restricted set of functionally active chemokine 
receptors capable of promoting migration to pancreatic islets. Blood 106: 419-427.

SORIA, B. (2001) In-vitro differentiation of pancreatic beta-cells. Differentiation 68: 205-219.

SPOONER, B.S., WALTHER, B.T., and RUTTER, W.J. (1970) The development of the dorsal and ventral mammalian pancreas in vivo and in vitro. J. Cell Biol. 47:235-246

STAGNER, J., AHREN, B., SUNDLER, F., and WHITE, K. (2008) Reconstructing the pancreas: restoration of normoglycemia, exocrine function, and islet innervation by islet transplantation to the pancreas. Transplant Proc. 40: 452-454.

STOLAR, M. (2010) Glycemic control and complications in type 2 diabetes mellitus. Am. J. Med. 123:S3-11.

TAHRANI, A.A., BAILEY, C.J., DEL PRATO, S., and BARNETT, A.H. (2011) Management of type 2 diabetes: new and future developments in treatment. Lancet. 378: 182-197.

TAKAHASHI, K., TANABE, K., OHNUKI, M., NARITA, M., ICHISAKA, T., TOMODA, K., and YAMANAKA, S. (2007) Induction of pluripotent stem cells from adult human fibroblasts by defined factors. Cell 131: 861-872.

TANG, D.Q., CAO, L.Z., BURKHARDT, B.R., XIA, C.Q., LITHERLAND, S.A., ATKINSON, M.A., and YANG, L.J. (2004) In vivo and in vitro characterization of insulinproducing cells obtained from murine bone marrow. Diabetes 53: 1721-1732.

TESAR, P.J., CHENOWETH, J.G., BROOK, F.A., DAVIES, T.J., EVANS, E.P., MACK D.L., GARDNER, R.L., and MCKAY, R.D. (2007) New cell lines from mouse epiblast share defining features with human embryonic stem cells. Nature 448: 196-199.

THATAVA, T., NELSON, T.J., EDUKULLA, R., SAKUMA, T., OHMINE, S., TONNE, J.M., YAMADA, S., KUDVA, Y. TERZIC, A., and IKEDA, Y. (2011) Indolactam V/GLP-1-mediated differentiation of human iPS cells into glucose-responsive insulin-secreting progeny. Gene Therapy 18: 283-293.

THOMSON, J.A., ITSKOVITZ-ELDOR, J., SHAPIRO, S.S., WAKNITZ, M.A., SWIERGIEL, J.J., MARSHALL, V.S., and JONES, J.M. (1998) Embryonic stem cell lines derived from human blastocysts. Science 282: 1145-1147.
TIMPER, K., SEBOEK, D., EBERHARDT, M., LINSCHEID, P., CHRIST-CRAIN, M. KELLER, U., MÜLLER, B., and ZULEWSKI, H. (2006) Human adipose tissuederived mesenchymal stem cells differentiate into insulin, somatostatin, and glucagon expressing cells. Biochem. Biophys. Res. Commun. 341: 1135-1140.

TROVATO, L., DE FAZIO, R., ANNUNZIATA, M., SDEI, S., FAVARO, E., PONTI, R. MAROZIO, L., GHIGO, E., BENEDETTO, C., and GRANATA, R. (2009) Pluripotent stem cells isolated from human amniotic fluid and differentiation into pancreatic beta-cells. J. Endocrinol. Invest. 32: 873-876.

WEIR, G.C., CAVELTI-WEDER, C., and BONNER-WEIR, S. (2011) Stem cell approaches for diabetes: towards beta cell replacement. Genome Med. 3: 61

WEN, Y., CHEN, B., and ILDSTAD, S.T. (2011) Stem cell-based strategies for the treatment of type 1 diabetes mellitus. Expert Opin. Biol. Ther. 11: 41-53.

XIA, B., ZHAN, X.R., YI, R., and YANG, B. (2009) Can pancreatic duct-derived progenitors be a source of islet regeneration? Biochem. Biophys. Res. Commun. 383: 383-385.

YI, S.Q., SHIMOKAWA, T., AKITA, K., OHTA, T., KAYAHARA, M., MIWA, K., and TANAKA, S. (2003) Anatomical study of the pancreas in the house musk shrew (Suncus murinus), with special reference to the blood supply and innervation. Anat. Rec. A Discov. Mol. Cell Evol. Biol. 273: 630-635.

YU, J., VODYANIK, M.A., SMUGA-OTTO, K., ANTOSIEWICZ-BOURGET, J., FRANE, J.L., TIAN, S., NIE, J., JONSDOTTIR, G.A., RUOTTI, V., STEWART, R., SLUKVIN, I.I., and THOMSON, J.A. (2007) Induced pluripotent stem cell lines derived from human somatic cells. Science 318: 1917-1920.

ZHOU, Q., BROWN, J., KANAREK, A., RAJAGOPAL, J., and MELTON, D.A. (2008) In vivo reprogramming of adult pancreatic exocrine cells to beta-cells. Nature 455: 627-632.

ZUK, P.A., ZHU, M., ASHJIAN, P., DE UGARTE, D.A., HUANG, J.I., MIZUNO, H., ALFONSO, Z.C., FRASER, J.K., BENHAIM, P., and HEDRICK, M.H. (2002) Human adipose tissue is a source of multipotent stem cells. Mol. Biol. Cell 13: 4279-4295. 


\section{Further Related Reading, published previously in the Int. J. Dev. Biol.}

Pdx1-transfected adipose tissue-derived stem cells differentiate into insulin-producing cells in vivo and reduce hyperglycemia in diabetic mice

Hiromitsu Kajiyama, Tatsuo S. Hamazaki, Makoto Tokuhara, Shinji Masui, Koji Okabayashi, Kiyoshi Ohnuma, Shigeharu Yabe, Kazuki Yasuda, Shoichi Ishiura, Hitoshi Okochi and Makoto Asashima

Int. J. Dev. Biol. (2010) 54: 699-705

Characterization of mouse embryonic stem cell differentiation into the pancreatic lineage in vitro by transcriptional profiling, quantitative RT-PCR and immunocytochemistry

Alexandra Rolletschek, Insa S. Schroeder, Herbert Schulz, Oliver Hummel, Norbert Huebner and Anna M. Wobus Int. J. Dev. Biol. (2010) 54: 41-54

Mouse ES cells over-expressing the transcription factor NeuroD1 show increased differentiation towards endocrine lineages and insulin-expressing cells

Mélanie Marchand, Insa S. Schroeder, Suzy Markossian, Anouchka Skoudy, Didier Nègre, François-Loïc Cosset, Paco Real, Christian Kaiser, Anna M. Wobus and Pierre Savatier Int. J. Dev. Biol. (2009) 53: 569-578

Expression of regulatory genes for pancreas development during murine embryonic stem cell differentiation

Josué K. Mfopou, Erik Willems, Luc Leyns and Luc Bouwens

Int. J. Dev. Biol. (2005) 49: 915-922

Sox9, a novel pancreatic marker in Xenopus Young-Hoon Lee and Jean-Pierre Saint-Jeannet Int. J. Dev. Biol. (2003) 47: 459-462

Genes controlling pancreas ontogeny

Claire Bonal and Pedro L. Herrera

Int. J. Dev. Biol. (2008) 52: 823-835

5 yr ISI Impact Factor $(2010)=2.961$

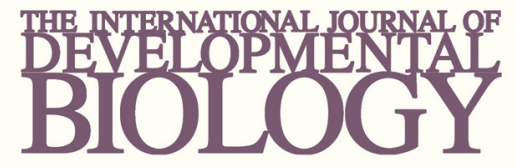

Volume 54 Nos. 6/7 Special Issue
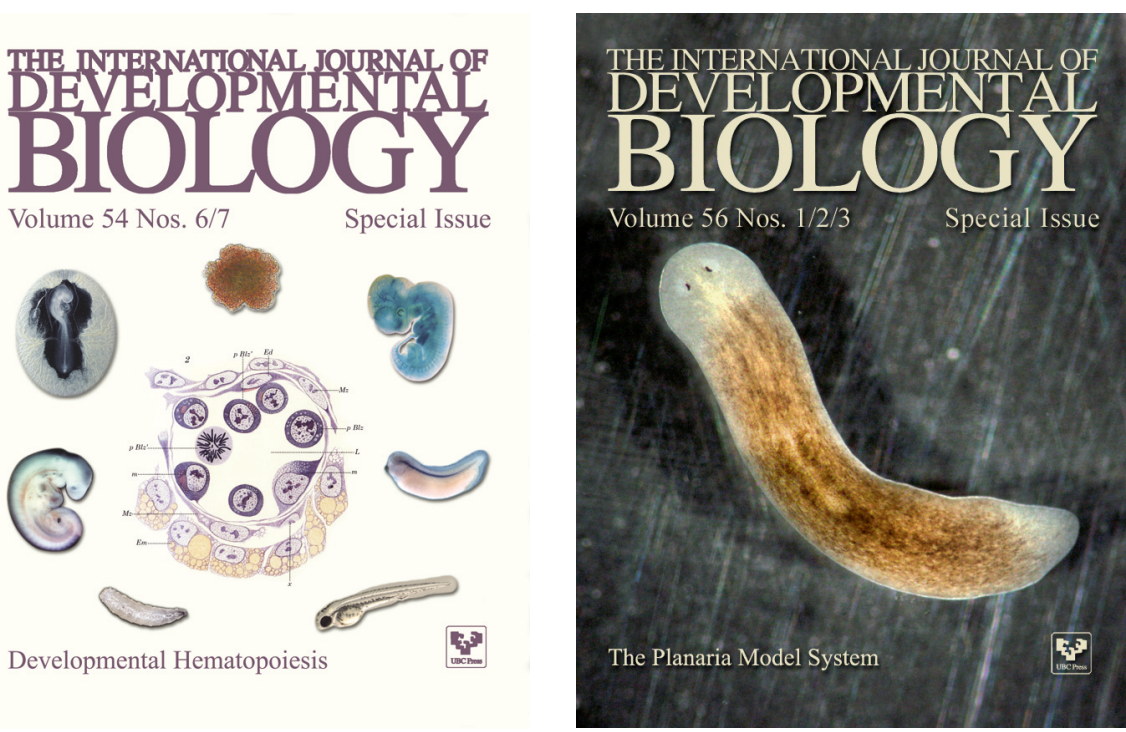
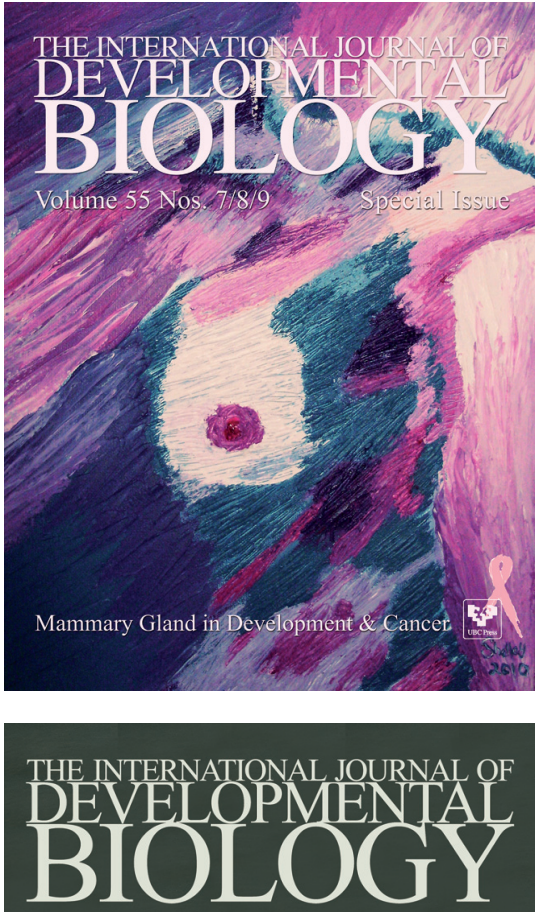

Volume 55 Nos. $4 / 5$

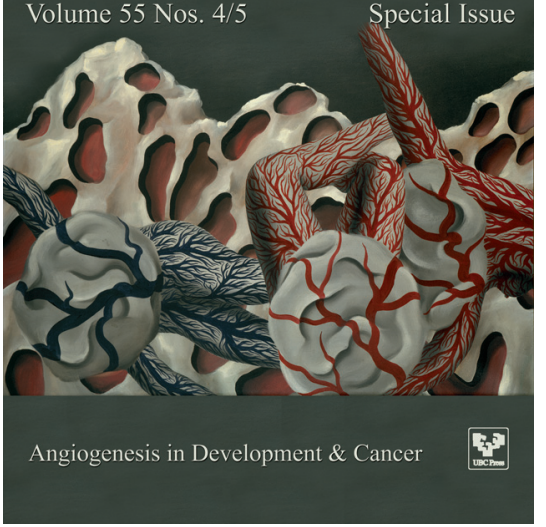

